\title{
Indigenous Spirituality in the Touristic Borderzone: Virtual Performances of Sámi Shamanism in Sápmi Park
}

\author{
STEIN R. MATHISEN \\ Finnmark University College
}

\begin{abstract}
For tourists travelling to the northernmost parts of Europe, the tour includes not only experiences of wild nature, Midnight Sun, and Aurora Borealis, but also encounters with the indigenous Sámi people who populate the area. Emblematically represented in tourist guidebooks as reindeer herders, the Sámi stand out as representatives of a life lived in close contact with nature, and as carriers of an indigenous spirituality that reflects a deep concern for the environment and for the powers found in nature. How can this insight be represented or performed in tourism? The article discusses the representation of this image of the Sámi in a theme park in the village of Kárášjohka, Norway. Transposed to the stage of the experience industry in the Sápmi Magic Theatre, a virtual Sámi shaman narrates to tourists the story of an ancient indigenous wise man. This narrative is on the one hand deeply embedded in Western imaginaries about the Noble Savage and about a prelapsarian, pre-colonial past. On the other hand, this myth is represented as something belonging to a more glorious past, and not as part of present-day indigenous life. From the point of view of ethno-politics, such narratives may support Sámi claims of representing a unique culture, while at the same time constituting a threat to the fight for an equal position in contemporary society.
\end{abstract}

Keywords: ethno-politics, indigenous spirituality, Sámi shamanism, theme park, tourism

At the Sápmi Park, a tourist theme park in the village of Kárášjohka ${ }^{1}$ in Finnmark, Norway, tourists are promised the chance to experience the 'genuine' culture of the Sámi people, the indigenous population of northern FennoScandia and the Kola Peninsula. The theme park's homepage promotes an 'authentic experience of the Sami culture', advertising the following main attractions: 'Taste the Sami cuisine! Catch the smell of open fire! Feel the

1 The place-name also has the form Karasjok, a Norwegianized spelling of the Sámi rendering of the name. The name is associated with the river running through the village, johka being the Sámi word for 'river', while the first part of the name is probably derived from the Finnish kara, 'bending'. 
softness of reindeer rugs! $!^{2}$ Enjoy a multimedia show about the Sami way of life! Listen to joik, the traditional Sami song!' (www.sapmi.no.) This marketing echoes the ideas of the modern 'experience economy' (Pine \& Gilmore 1999), and can be read as a materialization of how meaningful experiences should be organized in these contexts (see Boswijk \& Thijssen \& Peelen $2006,92)$. Tourists are promised the opportunity of a full experience of Sámi culture, literally through every one of the five human senses. But another important attraction in the theme park actually offers tourists an experience connected with the sixth sense. This takes place in the 'Sápmi Magic Theatre', where tourists encountering a virtual representation of a Noaidi, the Sámi shaman, are offered a chance to experience the spiritual world of the Sámi, as it existed before the arrival of Christianity. These 'otherworldly' experiences might even give tourists a basis 'for a deeper understanding of the origin of life and the power of nature', which is said to 'help you understand your own place in nature and the surrounding world' (Sapmi 2002). Tourists are guided toward these various experiences on offer in the theme park by signposts made in the shape of Sámi shaman drums, again emphasizing the spiritual route visitors are about to follow. But why have signs of spirituality become so important in a Sámi theme park?

In this article I take a closer look at how a specific version of indigenous spirituality and religion is presented in a contemporary touristic display, taking the Sápmi theme park's exhibition of pre-Christian Sámi religious myths and spirituality as a point of departure. What is staged and performed in this park is related, at least thematically, to central elements of indigenous Sámi belief and spiritual life. It therefore forms an important part of what is considered Sámi indigenous cultural heritage. At the theme park, however, what is at the core of the product being presented is entertainment and an 'experience'. The focus here will be on how this presentation has been staged and organized (Edensor 2001), and on the kinds of narratives concerning Sámi spirituality that are being offered in this contemporary tourist presentation of a past culture. This narration and performance of Sámi shamanism in a touristic context raises further questions concerning the cultural and ethno-political implications of such presentations of indigenous spirituality.

\section{Nature, Indigenous Sámi, and Northbound Tourism}

Most tourists travelling to the far north of Scandinavia's Arctic areas are seeking an extraordinary nature experience, such as for example the Mid-

2 I.e. reindeer pelts. 
night Sun during the summer, or the Aurora Borealis during the winter. Or they may be simply en route to set foot on the northernmost point of the European mainland, the North Cape. ${ }^{3}$ During their travel northward, however, tourists are likely to encounter the Sámi people. This combination of a wild and (for the most part) uninhabited nature and an encounter with what tourist guidebooks describe as a 'people of nature', often described in travel literature as 'Europe's last nomads' (for example Arthaud 1956), stands out as appealing to many tourists visiting the area from more urban and densely populated areas. Thus the Sámi, especially those occupied with reindeer-herding activities, have become a forceful and picturesque materialization of certain attractive aspects of the Arctic landscape and its inhabitants.

In a historical perspective, various groups of Sámi have relied on subsistence economies, with fishing as a main activity among the Coastal and River Sámi and hunting and reindeer herding among the Mountain Sámi. Some contemporary Sámi still work within these traditional economies. Present-day Sámi, however, are integrated into the modern economy, and the majority are employed in all sectors of modern society. Yet reindeer herding still holds a symbolic position as representing the 'genuine' Sámi way of life. It is therefore this part of Sámi culture that is most often presented to outsiders, and in the tourism industry the reindeer herder is the 'emblematic' Sámi (Olsen 2003). With its closeness to nature, reindeer herding has become a symbol of Sámi culture, as a way of life based on traditionalism, harmony, spirituality, and ecological attitudes towards nature (Mathisen 2003). These can all be observed as central elements in contemporary descriptions of other indigenous populations throughout the world, often serving on the one hand as a basis for indigeneity as an ethno-political project, on the other forming an important element of popular myths about certain indigenous peoples in mass media products such as comics, magazines and films. The boundary between popular myths or narratives about indigenous people and representations of these cultures in tourism is often unclear or fuzzy. Sámi organizations in Finland have been protesting against the abuse and exploitation of Sámi culture in the Santa Claus Theme Park in Rovaniemi, pointing to a "fake "shamanistic" ceremony about crossing the Arctic Circle', as well as other misrepresentations of Sámi culture (Suoma Sami Nuorat internet page; see also Comaroff \&

3 The North Cape is actually situated on an island (the Norwegian Magerøya, Sámi Máhkarávju), and is not even the northernmost point of that island. Nevertheless the cliff has a long history of representing northernmost Europe in literature and tourism (see Jacobsen 1997, 341ff.). 
Comaroff 2009, 159). Similar strong protests, however, have not been voiced against the presentations at the Sápmi Park in question here. Tourism can be understood as a kind of 'experience' industry; it has a strong economic interest in offering elements from the domain of popular culture to tourists, but it also needs to take into account possible conflicts that might arise from over-commercialization or from overly biased representations of an indigenous population. This shows some of the complexity involved in a concept like Sámi spirituality, relating to religion and individual development, to tourism and ethno-politics, to spiritual experience and a concern for environmental issues. The construction of a Sámi theme park focusing on Sámi spirituality, in the middle of the core Sámi area, thus gives rise to many questions. The staging of a performance also involves certain broader contexts, relating to representations of indigenous people and to the role of these representations in the wider ethno-political context.

\section{Pilgrimages: Finding Otherness in the Touristic Borderzone?}

With the help of travel agencies, tourist offices and pre-packaged trips, today's tourists can find their way to almost any geographically distant destination around the world. But crossing national borders and visiting remote places is not the only objective of leisure travel. The interests of some tourists go beyond space and geographical movement, and express a desire to cross boundaries of time to visit old and pre-modern cultures. Modern tourists also want to experience cultures that are seen as belonging to another time, where people live under more 'primitive' conditions, but also in closer contact with nature and its forces. As Edward Bruner puts it, modern international mass tourism does not recognise national borders (Bruner 2005, 191); it is constantly on the search for 'authentic' and 'genuine' cultures from the other side of a supposed boundary between modern and traditional, between the present-day and the historical, between 'Us' and 'Them'. The cognitive construction of this boundary is based on a long history of Western imaginaries and narratives, myths about the 'Other', and an implicit Occidental identity formation which sees European culture and lifestyle as the most 'civilized' and most modern. The flip side of this coin is the exoticisation of other cultures, identifying tradition, authenticity and originality as something to be found primarily among these 'Others'.

This tendency has been described as a driving force in modern tourism by a wide range of scholars and from various perspectives (for example MacCannell 1976; Graburn 1989; Kirshenblatt-Gimblett 1998; Bruner 2005), 
and it touches upon many important questions relevant to cultural studies and tourism studies, with regard to the cultural constitution of the 'Other' in a touristic context. But it is also relevant for the study of religion; the beliefs and cosmologies of the cultures and peoples being targeted as tourist destinations are serving in various ways as attractions in tourism marketing and destination development. Religious beliefs and performances can be packaged and marketed as 'exotic', 'colourful', and 'aboriginal'; but also as promising 'a deeper understanding of the origin of life', and the chance to 'see the world in a different light' after the visit (Sápmi 2002). Certain dreams and myths, where man is understood as living in a close and unspoilt relation to nature and its forces, offering the possibility of experiencing a happier, more harmonious way of life, are tied to actual indigenous people, and put on display for tourists to experience in various ways.

Scholars of tourism have also in different ways used concepts from religious studies in order to better understand the phenomenon of tourism, as well as more specific activities within the touristic field. In a historical perspective, modern tourism has been compared to the travels performed by pilgrims to holy lands or holy places (Turner \& Turner 1978; Franklin 2003, 122-9), and the pilgrim has been seen as a predecessor to the contemporary tourist (Urry 1990,4). Theories of ritual and pilgrimage (van Gennep 1960; Turner 1969; Turner \& Turner 1978) have also inspired more recent interpretations of the touristic itinerary. In his article 'The Sacred Journey', the American anthropologist Nelson Graburn (1989) takes Edmund Leach's structural understandings of ritual as a point of departure (see for example Leach 1976), and discusses similarities between ritual and tourism. Just as religious rituals, such as the rite de passage, convey the individual between profane and sacred stages, the touristic journey similarly carries the tourist through different stages, where work and everyday life can be compared to the profane, while a tourist holiday can be seen as analogous to occupying a sacred status (Graburn 1989, 25). Thus tourism represents a journey out of the ordinary and into something non-ordinary, separate from everyday life and work. Remaining in this extraordinary status during the holiday also holds the potential of transforming one as a person, so that when one re-enters one's everyday routines one does so as a new kind of person.

These parallels drawn between tourism and religion point to an understanding of tourism as an activity with the potential to transform people's lives. Dean MacCannell (1976) introduced the idea of tourism as a kind of modern pilgrimage. He saw tourists as trying to escape the constraints of ordinary, modern life and seeking the genuine experience of a more tradi- 
tional culture. This was also described as an assumed search for a lost, more holistic experience in the present-day, modern reality, now appearing as fragmented and divided. In short, tourists wanted to experience 'authenticity'. As MacCannell maintained, this 'authentic' experience nevertheless turned out to be difficult to find, as most experiences available to groups of tourists were arranged or staged in one way or other (MacCannell 1976). But touristic arrangements need not only be viewed as destructive to authentic culture. They also constitute new ways of understanding cultural expression, and in that sense they produce new, authentic cultures, even when they are commercialized (Comaroff \& Comaroff 2009).

Tourism usually involves various material and organisational practices, intended to support certain ways of experiencing a culture. When the touristic experience is staged (Edensor 2001), it must also be realized that the tourist has access only to certain arenas of a culture. The anthropologist Edward M. Bruner calls this the 'touristic borderzone', and writes about it as an arena where both tourists and the local population are constantly moving in and out of the zone:

The touristic borderzone is like an empty stage waiting for performance time; this is so for both the audience of tourists and for the native performers. The natives too, then, move in and out of the touristic borderzone. But the perceptions of the two groups are not the same, because what for the tourists is a zone of leisure and exoticization, for the natives is a site of work and cash income. (Bruner 2005, 192.)

The analysis of the context, and the arrangement of the touristic performance, points to the important observation that a very specific constitution of religion as cultural heritage is being performed in this 'touristic borderzone'. Despite the theatrical set-up, all roles are not necessarily given or fixed (ibid. 18). The performance of an indigenous spiritual culture has the potential to change opinions and values among visiting tourists as well as among the indigenous people being represented, exhibited, and performed.

The concept of 'heritage', which has gained in popularity over the past decades, is also illustrative of the kind of processes that are going on. 'Heritage is a new mode of cultural production in the present that has recourse to the past', as Barbara Kirshenblatt-Gimblett $(1998,149)$ so eloquently puts it. This 'production' does not mean that the presented culture is invented or inauthentic (ibid. 150), but rather that new ways of presenting what appears to be old elements of culture create new meanings and new values 
in new contexts. Because of its economic aspect tourism is an important arena for heritage production and representation, and it is therefore important to understand whether, and how, touristic presentations influence contemporary understandings of indigeneity and spirituality. This implies taking a closer look at how heritage production adds 'the value of pastness, exhibition, difference, and, where possible, indigeneity' (ibid.) to, in this case, religious practices that are understood as having already disappeared or in danger of doing so.

\section{Presenting the Past in the Present}

Sápmi Park, a tourist theme park in the village Kárášjohka in Finnmark, Norway, can serve as a starting point for a discussion of the actual framing and organization of a touristic experience involving an indigenous population and their spiritual life. This theme park was established in conjunction with the hotels of the Norwegian Rica Hotel franchise in the year 2000. The whole idea of setting up a theme park had been developed with the explicit aim of presenting Sámi culture to tourists travelling through the area, on their way to other destinations. The village of Kárášjohka is situated in the middle of what is usually designated as the core Sámi area of Norway, so there should logically be no need to set up a theme park to be able to present genuine and authentic Sámi culture. Part of the problem in relation to tourism, however, has been that this modern Sámi village does not stand out visually with the kind of 'Sámi-ness' that visiting tourists would expect to find. Exactly what the tourist would expect to find might be so self-evident that no explanation had to be given - which is an interesting observation in itself. The expectations of visiting tourists are of course based on the longer history of describing this indigenous population (by their 'Others', see Mathisen 2003), as well as on the marketing that the tourists have been exposed to prior to their choice of travel destination (for straight congruence with historical descriptions, cf. Olsen 2003; 2008; Viken 2006). The problem of meeting tourists' expectations of a Sámi way of life actually belonging to the past has been pointed out by many tour operators in the Sámi area. The solution was to construct a Sámi theme park, where what happened inside the park could be controlled and given the right 'quality', corresponding to what visiting tourists would expect to find in an area populated by an indigenous population like the Sámi.

Some idea of the ambience the owners of Sápmi wanted to create with this theme park can be seen already in the information leaflet given to tour- 
ists as they enter the site, featuring old, sepia-toned photographs of Sámi occupied in traditional reindeer herding activities. Newer, colour photographs feature colourful, traditional Sámi clothing, handicraft, and ancient mythology. These images lead the visitor to expect to find an 'authentic' and traditional Sámi culture behind the gates to the park, and there are obvious visual references to the antiquity and indigenous originality of this cultural adaptation to a life close to nature, the environment and the reindeer.

The actual framing of this park is also telling, and gives a first and introductory approach to a description of the site. On two sides the area is surrounded by Rica Hotel buildings, on the third side we find a large souvenir shop and a café. The fourth side is formed by the main road, where most of the tourists travelling through Finnmark on their way to the North Cape pass by. Here we also find the parking lots, with ample space for cars, campers and tourist buses.

In making this stop along the road, travellers and tourists are also invited to make a kind of temporal stop. They are given the impression of entering an old world; once they have paid their admission fee at the gate, they are somehow outside ordinary time. 'The Sápmi Theme Park invites you into the world of the Sámi people - to see their past and their present. Perhaps you'll even be able to glimpse what the future holds in store as well?' as the information folder puts it (Sápmi 2002). Most of the cultural sights tourists encounter in this theme park are oriented toward the past, even though the presentations are contemporary, in fact often technologically quite sophisticated and modern. The out-of-time experience offered in this tourist theme park is the same as the 'ethnographic present' people are used to finding in ethnographic museums, or reading about in more traditional ethnographic monographs of 'primitive' cultures.

The actual framing, or enclosure, of the theme park reveals that the area and its content has been removed from an earlier context and reconstructed in a new one. You have to pay to enter; but once you have done that, both your admission and your freedom to observe everything is ensured by a badge on your sleeve. You are free to gaze at everything, and to take photos. You get a map of the park, and you can plan your own way through the enclosed landscape. This part of the theme park is called 'Sámi Siida'. One model for this kind of arrangement is the typical Scandinavian openair museum. Already when Arthur Hazelius first carried out his idea, at Skansen in Stockholm, of an outdoor museum where traditional buildings from different parts of Sweden would be presented in a 'natural' context, it 
incorporated a Sámi camp, with live Sámi and reindeer. ${ }^{4}$ At the Sámi theme park in Kárášjohka a relatively large area - into which tourists are led by a path - has been set aside, with a variety of traditional buildings and with the utensils used in reindeer herding. The area features the buildings of the traditional summer camp, with various tents (lavvu) on one side of the path, and the more permanent buildings of the winter camp (siida) in wood and turf on the other. The material culture that is exhibited in this way can all in all be characterized as belonging to the traditional culture of the nomadic reindeer-herding Sámi. It gives a picture of how things used to be in a not too distant past, but it can hardly be interpreted as a consistent picture of how things are today.

All the same, this museumised version of Sámi reindeer-herding culture is populated with live Sámi in traditional clothing. They are occupied in what seems to be their daily duties, such as, for the women, making traditional Sámi clothing or handicraft (duodji). The men are taking care of live reindeer, which are fenced off in a separate enclosure within the area. With their reindeer, this Sámi family is 'authentic' in the sense that they earn their daily livelihood in reindeer herding. But rather than following the rest of their herd and their siida on the annual migration with the reindeer to the summer pastures on the coast, they have chosen to stay at the winter pasture area in Kárášjohka with this small reindeer herd, in the service of the local tourism industry. Although the money earned from tourism is probably marginal, this represents a combination that is not at all unusual among contemporary Sámi reindeer herders. Tourists travelling along the main roads to the North Cape encounter, at not very long intervals, characteristic 'shacks' along the road, where Sámi in their traditional costumes offer souvenirs, dried reindeer meat, and reindeer pelts and antlers for sale (Olsen 2003, 11ff.). However, while many of these roadside businesses are private, with little organization, the families entering into contract with the Sámi theme park are more restricted by certain rules and quality standards in order for their handicraft products to be eligible for sale in the souvenir shop. Over the years this has caused some problems in cooperation.

Thus there is some tension between the museum-like appearance of the theme park and the integration of a Sámi reindeer-herding family that is in active business today. But this may not be visually accessible to the tourists; what they can observe of Sámi life pretends to be backstage, but in the reality these Sámi are presenting a front-stage version of traditional Sámi

4 Live Sami with reindeer were already exhibited in William Bullock's Egyptian Hall in London in 1822 (see Kirshenblatt-Gimblett 1998, 45; Mathisen 2007). 
life for tourists. Opportunities for a touristic experience are more important in this context than the transmission of historical knowledge. Sapmi Park is a place to experience Sámi everyday life as it once was, or as it has been presented in various narratives about 'the Last Nomads of Europe'. Visually the Sapmi Park is something between the traditional open-air museum of the Scandinavian or Skansen type and the typical Disneyland amusement park, with its themed narratives, live experiences, and enacted culture (cf. Bryman 1999). On closer inspection, the performative organization of the theme park directs visitors towards the consumption of experiences, and each individual element is constructed toward this end. One of the buildings in the winter siida is not actually traditional, but is typical of the adjustment of a Sámi siida to tourism; it can be found in other touristically organized locations as well. This is a very large tent (stuoragoahti), with a structure resembling the traditional Sámi tent but with space for up to 60 persons. The function of this tent is specifically to serve large groups of tourists, either for consuming a meal or coffee or for the consumption of arranged representations of Sámi culture. In the tourist season the public is invited to listen to daily presentations of old (and modern) traditional Sámi singing (joik). The theme park is a place that has been constructed to allow visitors to experience the past as a value in the present. The park is a representation of indigenous heritage through exhibition. As we shall see, the locus of the touristic borderzone, through the use of virtuality, creates an arena where it is also feasible to offer a mythical narrative of the intangible Sámi cultural heritage.

\section{From Supernatural Narratives to Virtual Experience}

According to Barbara Kirshenblatt-Gimblett, 'a key to heritage productions is their virtuality' $(1998,166)$. Exhibiting the Sámi spiritual heritage offers the problem of putting on display something that is intangible, where there are no actual objects to be touched or gazed upon. But like travel into the past, Sámi spirituality too can be produced and constructed in the touristic borderzone. Another important part of the Sámi theme park is the 'Sápmi Magic Theatre'; this can be described as a separate scene within the larger arena of the theme park, specifically designed to present the spiritual heritage of the Sámi people. The telling of this narrative takes place primarily at Stálubákti, literally 'the cliff of the Stallos', ${ }^{5}$ but translated as 'Spirit Rock'

5 In Sami narratives, the Stálo is a giant dressed in steel armour. Some scholars have interpreted these narratives as reflections of ancient encounters between the Sami and steel armoured Vikings, or between tax collectors from warring neighbouring kingdoms. 
(Sápmi 2002) - or, better, 'The Sápmi Magical Theatre', as the creators of the show (see below) have chosen to call it. Sámi spiritual culture and religion is a cultural domain that is not easily represented in a traditional museum exhibition. A great deal of effort and money has been invested in this presentation, and what was then (the Sápmi Park opened in 2000) the most up-to-date media technology was applied in visualizing the old Sámi religion, myths and narratives. To develop this product the people behind the Sápmi theme park contacted BRC Imagination Arts, an international company established in 1981, with offices in the US and some European countries. This company develops visual presentations using the most modern digital technology, and has cooperated with movie producers, international exhibitions, museums and theme parks all over the world (cf. their homepage at http://www.brcweb.com/).

The present theatrical performance offers an interesting mixture of modern media technology and ancient Sámi mythology. It is presented by the company as follows:

Located literally at the end of the Earth, the Sápmi Magic Theater is a stateof-the-art immersive visitor center featuring a BRC Magic Theater located in Kárášjohka, Norway. Utilizing a startling array of cutting-edge technical wizardry, the Sápmi Magic Theater transports us into the mystical world of the indigenous Sámi people and harnesses the power of ancient Sámi myths to speak directly to our souls. [...] Layered digital image technologies and special in-theater effects including smoke, fog, fiber optics, illusions and more, immerse you completely in the Sámi worldview, opening your heart and mind to a new way of thinking about life.

(http://www.brcweb.com/projects/2-3/2-3-7.html)

This is a kind of media technology that through the end of last century seemed to invade not only the movies, but also amusement and theme parks of all sorts, as well as more traditional museums trying to update and popularize their exhibitions. Tourism was often at the cutting edge of this development. But behind all the technology there is a narrative to be told. This is also an important part of the company's self-presentations. Under the heading 'World Class Story Telling', they market themselves in this way on their homepage: 'We are your mythmakers. Do you have a story to tell?' (http://www.brcweb.com/worldclass.html). So, what is the story here?

This magical theatre or multimedia show is presented in eight optional languages and consists of two successive performances, taking place at two 
different locations. The first performance takes place in a square room, presenting an introductory, museum-like exhibition giving information about the different groups of Sámi to be found in the northern areas, as well as their typical geographical and natural environments. After this their historical background and traditional way of life is presented on a screen, with commentaries visually accompanied by pictures, old black and white movies, and newer film clips. The narrative thread in this presentation focuses at the tension between the old and the traditional lifestyle among the Sámi, and the emerging threat from modernity and new technology. This continues with film clips showing the modern and contemporary way of life among reindeer Sámi, with satellite TV shows from modern international media producers instead of narratives around the bonfire, and the extensive use of motorized transportation in a fragile natural environment, with snowmobiles, four-wheeled motorbike, and helicopters replacing traditional reindeer-drawn transportation. In the last scene of the film an old Sámi man enters a helicopter, now commonly used in reindeer herding; lifting for the sky in turbulence and heavy noise, a voiceover rhetorically asks what the man's forefathers would have thought of this use of nature and the tundra.

Then the film ends, and the audience is invited to take part in a journey into the spiritual world of the Sámi. Visitors are led through a narrow, mazelike passage into the next room. This space is circular, and is designed as a giant Sámi tent. One half of the circle consists of seats for the spectators, while the other half is a screen. At the centre of the room a fire is simulated using modern visual technology: in the smoke from this fire the face of the old Sámi in the helicopter reappears, but this time he presents himself as an old Sámi shaman (noaidi). ${ }^{6}$ He wants to tell us the true story of the Sámi way of life and of their relationship to nature and the powers found there. His story is accompanied by lights and sounds creating a mystical atmosphere, along with beautiful images of the Arctic landscape appearing on the screen, while an artificial Aurora Borealis glows on the ceiling and stars are set alight.

Through this digitalized narrative an old, mythical Sámi world is evolving, at the same time linked with ideas in current global distribution connected to indigenous people, nature preservation and environmental

\footnotetext{
6 Sámi shamans are found throughout the Sámi area; they can be visited for healing or consultation, or to experience a 'drum journey'. These shamans operate in terms of more or less traditionally based knowledge, but many of them are also influenced by various forms of neo-shamanism and present-day New Age ideas. This is probably not easily accessible for mainstream or group tourism, but may be more popular among individual travellers.
} 
organizations. This linking of indigenous people and a closeness to nature is recognizable from Hollywood films, New Age literature, and a multitude of other media presentations. It is therefore familiar to tourists visiting the theme park, regardless of their country of origin. The narrated story is exotic and localized to the places and landscapes they are at the same time visiting in the far north. But the story already resembles something they have previously heard, and parallels other globally prevalent narratives. Indigenous spirituality has been transformed into the language of the world of magic of the new experience economy, but maintains, in the present context, a solid basis in the indigenous cultural heritage.

Most important is perhaps the fact that this part of the Sami exhibition tells a mythical narrative about Sámi culture and spirituality, which in the current political context has some wider implications. Although the story told at the Sápmi magic theatre features digital images and uses various forms of modern technology, it is not entirely new in its content. Descriptions of the Sámi in old myths and narratives produced by neighbouring peoples have always been marked by ambiguity. The Sámi and their close relationship toward nature has led outsiders to perceive them as 'children of nature', but this has had a double implication. From one point of view the Sámi represented an authentic and uncorrupted picture of man living in close contact with nature: the 'Noble Savage'. At the same time, however, they also represented the 'ignoble savage': irresponsible 'children of nature', much in need of paternalistic guidance from the ruling majority, who tended to see themselves as representing a higher level of civilization. This equivocal representation of an indigenous population is by no means unique to the Sámi, but can rather be seen as a recurring theme in the European understanding of 'other' and 'primitive' people. The simultaneous and rapidly shifting perception and representation of the 'primitive' as ignoble and noble savage places such people in a liminal position, in every sense of the word. They are seen at the same time as authentic human beings and as in need of 'domestication', so as to be able to leave their natural condition and enter into civilization.

Some of these older narrative versions of the Sámi continue to emerge in other media, while ethnographic research and ethno-politics have developed along new paths. As Barbara Kirshenblatt-Gimblett puts it in her book on heritage and tourism: 'Where do old ideas go to die? Tourism, a museum of the consciousness industry.' $(1998,176$.$) A new problem seems$ to arise when authentic human beings can no longer be found, because of the 'civilizing' process. Modernized and contemporary Sámi, according to 
this understanding, become representatives of unauthentic Sámi; this is in fact the central narrative of the Sápmi Magic Theatre. By this means the modern way of life that visiting tourists have just experienced at the centre of Kárášjohka and the exhibition of past, traditional Sámi culture that they just have witnessed in the ethnic theme park are implicitly combined and dealt with in the mythological narrative presented in the magic theatre. Sámi using motorized transportation and helicopters no longer represent the kind of spirituality with which the myth of the Noble Savage has associated them. But then this 'authentic' human being has to be reconstructed one way or another, to fulfil the expectations of the civilized and hegemonic visitors. An indigenous population may quite unexpectedly find themselves at the centre of such a reconstruction, with no real possibility of influencing the presentation that has been imposed upon them. The significance of the fact that this reconstruction takes place in the touristic borderzone, however, still needs some clarification.

\section{Consuming Culture and Signposting Shamanism}

This survey of the representation of Sámi material and spiritual culture at the Sápmi Theme Park has, perhaps not very surprisingly, led to the conclusion that everything is organized around a commercial idea: to sell the experience of an old, vanishing, and exotic culture. One further element in the representation of Sámi heritage in the theme park in Kárášjohka involves the rich opportunities for consumption. In that sense there are interesting parallels between the romanticizing of the old and traditional Sámi way of life and the commercialization surrounding the promotion of this culture. Visitors are given not only the opportunity to gaze at and experience Sámi culture, but also to consume elements from this culture (Lalvani 1995). Living reindeer can be gazed upon as they run in the fenced pen. But they can also be eaten, in the form of various traditional meals made with reindeer meat in the nearby restaurant.

One interesting observation in this connection is that only specific areas of Sámi culture stand out as consumable. In a historical perspective this parallels the exotic and romantic narratives about the Sámi created in ethnography. When traditionalized food is served in a reconstructed copy of an old Sámi 'gamme', sitting on reindeer pelts around an open fire, the food is labelled as Sámi. But when everyday food is served in the hotel's café, or in the theme park's cafeteria, it no longer has the label 'Sámi' attached to it. What is consumable as Sámi is connected to its 'otherness'. It has to be 
something that one way or another stands out from modernity, something that is experienced as different or exotic. Reindeer pelts fall into this category, and so do reindeer antlers and all kinds of souvenir products made from the reindeer. The large souvenir shop sells all kinds of Sámi handicraft, as well as Sámi clothing, jewellery, music and artwork, and literature about the Sámi culture.

The most precious object belonging to the spiritual Sámi heritage, the shaman's drum, can also be purchased as a souvenir, in every size. As we have already seen, this is the spiritual aspect of the Sámi heritage that in many ways links together the different parts of the theme park, and opens up ways of interpreting all parts of the exhibition. This is probably also why the Sámi shaman drum has been chosen as the image for all signposts in the park. Every part of the exhibitions, as well as the Magic Theatre, the restaurants, and the souvenir shop, are indicated by signposts in the shape of the shaman drum. Rather than symbolizing the various powers needed by the shaman to find his way on his journey to the Otherworld, however, the signs bearing the image of the drum now serve to orient visitors to a commercial experience within a constructed World of the Other.

Recognizing that the Sápmi theme park, as a touristic borderzone, constitutes a site that is to be understood as a theatrical performance, visited only by performers and spectators (Bruner 2005, 192), we might still expect that local people would occupy themselves with the actual content of these presentations. Representations of the Sámi past are connected with ethnic identity, with how the Sámi of the area perceive themselves and how they can accept being represented to the outside world. Representations of the Sámi might be linked to a less developed and less modern past, but should not be primitivised to such a degree that they appear stereotyped and offensive in the present ethno-political context. Edward Bruner writes about the touristic borderzone: 'Although the borderzone is about the local, what is performed there takes account of global and international flows.' (Bruner 2005,17 .) How is the representation of the Sámi culture in the touristic border zone related to other - political, social or commercial - representations of the Sámi in contemporary Norway? In order to understand its political implications, the touristic framing of this experience of Sámi culture needs to be placed in a wider frame of reference.

Sápmi Park focuses on the past in its representation of Sámi culture, and a specific understanding of Sámi spirituality is an important vehicle in these presentations. The present-day centre of Kárášjohka, however, holds few references to the past or even to an easily identifiable or distinguishable 
Sámi-ness at all. ${ }^{7}$ This absence is seen as a problem by the local authorities as well as by tourism enterprises based on Sámi culture. When tourists visit the centre of Kárášjohka, there are no visual indications that this is a Sámi area (Olsen 2003, 12). The bank, the café, the shopping centre, the parking lots, the roundabout, the roads, the snack bar and the gas stations all look the same as in any other Norwegian rural village. The people walking in the streets of course know that they themselves have a Sámi background or identity, but in everyday life there is no need for external symbols. Such symbols may play a role on more festive occasions, when people dress up in their characteristic folk costumes. There may also be the occasional old woman or man who shows up in traditional Sámi clothing when they visit the shop or the café. But this is not enough to present a coherent narrative about Sámi culture to outsiders.

Some of the new and emerging political interest in Sámi culture takes a new 'grand narrative', different from the colonialist idea of 'culture death', as its point of departure. Most research concerning the Sámi situation today is based on an understanding of the Sámi past as a history of suppression, with the present as a time of ethnic revival and a struggle for rights. The future is something that has to be politically defined by the Sámi people themselves, in terms of their own culture and traditions (Bruner 1986 refers to a parallel situation among Native Americans). In the late 1980s a Sámi ethnic revival began to take place. A decision by the Norwegian government in 1978 to dam the Alta River and build a hydroelectric power station was immediately met by organized protests from environmentalist organizations and local ethno-political activists. The question of Sámi rights in the area soon became a focal point in these protests. The most potent visual symbol of the uneven fight between the indigenous Sámi and the majority population represented by the Norwegian government was provided by a group of seven young Sámi enduring a hunger strike in a lávou (the traditional Sámi herding tent) outside the Norwegian Parliament in Oslo.

The events surrounding these protests introduced the Sámi and their situation to the media and the general Norwegian public, and connected these problems to the global focus on indigenous people and their political struggle to improve their conditions. Thus ethno-politics too eventually led to a revitalized interest in old Sámi folklore and culture. Artists, musicians, and young scholars who wanted to improve the political situation of the Sámi

7 Adding to the lack of a visual cultural past is the fact that during the last phases of World War II in 1944 the retreating German Army practiced a burnt-earth strategy; thus the area has no buildings antedating the war. 
began to explore the old Sámi culture, searching for building blocks for a new and proud Sámi identity. The traditional Sámi folk costumes were more commonly worn by young people, traditional crafts were revitalized, and folklore material was investigated in the search for a common background. This also guided artists, writers and scholars to sources describing the old Sámi religion and spiritual life, as it had existed before colonialism. Much in tune with the emerging and global movement of indigenism (Niezen 2003), this new ethno-political perspective gave rise to new literature, art and movies. One highly significant result of the demonstrations, actions and hunger strikes was the creation of a Sámi Parliament, with the power to issue statements and give political advice to the Norwegian Parliament on all political matters concerning the Sámi. In that sense the Sámi Parliament is a manifestation of the victorious ethno-political struggle among the Sámi, and a materialization of the new grand narrative of Sámi culture and heritage; not 'culture death', but a revival of the Sámi cultural heritage, and a struggle for political rights.

But the Sámi Parliament is also the closest neighbour of the Sápmi Theme Park in Kárášjohka. In their work, both of these institutions at some level rely on similar facts; that there is a significant cultural difference between the indigenous Sámi and the Norwegian majority population; that this difference is visible in certain important ways; and that the Sámi represent a genuine old culture that it is important to preserve. Since Kárášjohka has witnessed (at least so far) no major conflicts between Sámi ethno-politics and Sámi tourism, we might draw a tentative conclusion that at some point related processes regarding the use of cultural heritage are taking place in both these institutions. Some of the above-mentioned Sámi artists and culture workers who were active in the new revitalization of Sámi culture also in fact cooperated with the Sápmi Park and BRC Imagination Arts on the artistic and practical solutions in the exhibitions and the Magic Theatre. ${ }^{8}$ The manner in which this specific version of Sámi spirituality is located in the past, and indeed also in the touristic borderzone, renders it unproblematic for contemporary ethno-politics as long as it can be subsumed under the heading of cultural heritage, and as long as this is done in a sincere and respectful manner. Both heritage politics and ethno-politics use the past to create new meanings in the present.

The way the narrative of Sámi culture and spirituality in this representation is tied to urgent ecological questions adds to the political relevance

8 According to a permanent poster showing acknowledgements in the entrance area of the Magic Theatre. 
of the matter. The narrative of the ecological Sámi offers directions for a responsible contract with nature, based on another culture's spirituality, but with the potential of saving our mutual planet from disaster. But of course this is not the whole story, and there is much ambivalence in accepting this position. We have to realize that this narrative is also 'a fantasyland of the Western imaginary' (Bruner 2005, 193), deeply grounded in narratives about the Noble Savage. The negative side of this narrative is that it locates the Sámi population outside modern life and development, and legitimizes differences between the indigenous and majority populations. In this sense, the representations offered and the narratives told in the touristic borderzone can have negative consequences for contemporary indigenous life outside that zone.

Bibliography

Arthaud, Jacques

1956 Derniers Nomades du Grand Nord. Paris: Arthaud.

Boswijk, Albert \& Thomas Thijssen \& Ed Peelen

2006 A New Perspective on the Experience Economy - Meaningful Experiences. - Mika Kylänen (ed.), Articles on Experiences 3 - Christmas Experiences, 84-109. Rovaniemi: LCEEI.

\section{Bruner, Edward M.}

1986 Ethnography as Narrative. - Victor W. Turner \& Edward M. Bruner (eds), The Anthropology of Experience, 139-55. Urbana and Chicago: University of Illinois Press.

2005 Culture on Tour. Ethnographies of Travel. Chicago and London: The University of Chicago Press.

Bryman, Alan

1999 The Disneyization of society. - The Sociological Review 47, 25-47.

Comaroff, John L. \& Jean Comaroff

2009 Ethnicity, Inc. Chicago: Chicago University Press.

\section{Edensor, Tim}

2001 Performing tourism, staging tourism: (re)producing tourist space and practice. - Tourist Studies 1 (1), 59-81.

\section{Franklin, Adrian}

2003 Tourism: An Introduction. London: Sage Publications. 


\section{van Gennep, Arnold}

1960 (1909) The Rites of Passage. London: Routledge.

\section{Graburn, Nelson H. H.}

1989 (1977) Tourism: The Sacred Journey. - Valene L. Smith (ed.), Hosts and Guests. The Anthropology of Tourism, 33-47. (2. Ed.) Philadelphia: University of Pennsylvania Press.

1983 The Anthropology of Tourism. - Annals of Tourism Research 10, 9-33.

\section{Jacobsen, Jens Kristian Steen}

1997 The Making of an Attraction. The Case of North Cape. - Annals of Tourism Research 24, 341-56.

\section{Kirshenblatt-Gimblett, Barbara}

1998 Destination Culture. Tourism, Museums, and Heritage. Berkeley: University of California Press.

\section{Lalvani, Suren}

1995 Consuming the Exotic Other. - Critical Studies in Mass Communication $12,263-86$.

\section{Leach, Edmund}

1976 Culture and Communication. The Logic by which Symbols are connected. Cambridge: Cambridge University Press.

\section{MacCannell, Dean}

1976 The Tourist: A New Theory of the Leisure Class. New York: Schocken Books.

\section{Mathisen, Stein R.}

2003 Tracing the Narratives of the Ecological Sami. - Kirsti Pedersen \& Arvid Viken (eds), Nature and Identity. Essays on the Culture of Nature, 189-206. Kristiansand: Høyskoleforlaget. (Kulturstudier nr. 36.)

2007 Mr. Bullock's Exhibition of Laplanders. - Ottar 2007, 11-17.

\section{Niezen, Ronald}

2003 The Origins of Indigenism. Human Rights and the Politics of Identity. Berkeley: University of California Press.

\section{Olsen, Kjell}

2003 The Touristic Construction of the 'emblematic' Sami. - Acta Borealia 1/2003, 3-20.

2008 Identities, ethnicities and borderzones: Examplars from Finnmark, Northern Norway. Dissertation. Bergen: University of Bergen.

Pine, Joseph B. \& James H. Gilmore

1999 The Experience Economy. Work is Theatre and Every Business a Stage. Boston: Harvard Business School Press. 


\section{Turner, Victor W.}

1969 The Ritual Process. Chicago: Aldine.

\section{Turner, Victor \& Edith Turner}

1978 Image and Pilgrimage in Christian Culture: Anthropological Perspectives. Oxford: Blackwell.

\section{Urry, John}

1990 The Tourist Gaze: Leisure and Travel in Contemporary Societies. London: Sage Publications.

\section{Viken, Arvid}

2006 Tourism and Sámi Identity - An Analysis of the Tourism-Identity Nexus in a Sámi Community. - Scandinavian Journal of Hospitality and Tourism 6 (1), 7-24.

Pamphlets and Internet Resources:

Sápmi 2002: Velkommen til sápmi/Welcome to Sápmi. (Pamphlet from SAPMI AS, Kárášjohka)

Suoma Sami Nuorat: Protest against the exploitation of Sami culture. URL: http://boreale.konto.itv.se/rovaniemi.htm [visited 19.05.2009]

Velkommen til Sápmi temapark. URL: http://www.sapmi.no [visited 05.07.2002]

Welcome to BRC Imagination Arts. URL: http://www.brcweb.com/ [visited 05.07.2002 (old version), 04.06.2003 (newer version), 19.05.2009 (most recent version)] 